Paideusis

\title{
Heartmind Literacy: Compassionate Imagining \& The Four Brahmavihāras
}

\section{Claudia Eppert}

Volume 19, Number 1, 2010

URI: https://id.erudit.org/iderudit/1072320ar

DOI: https://doi.org/10.7202/1072320ar

See table of contents

Publisher(s)

Canadian Philosophy of Education Society

ISSN

0838-4517 (print)

1916-0348 (digital)

Explore this journal

Cite this article

Eppert, C. (2010). Heartmind Literacy: Compassionate Imagining \& The Four Brahmavihāras. Paideusis, 19(1), 17-28. https://doi.org/10.7202/1072320ar
Article abstract

This paper addresses the primacy of reason over emotion in much of Western philosophy and education. It brings Theravadan Buddhist wisdom to bear upon Western philosophical and educational conceptions of emotion, empathy, and compassion. More specifically, it discusses the four Brahmavihāras, or Divine Abodes. These abodes are considered boundless states of heartmind awareness that dismantle the bifurcation of mind/emotion and embody ideals of social engagement and peace. If cultivated, or dwelled in, they can overturn negative and destructive impulses, freeing the mind from greed, hatred, and delusion. They include Mettā, or loving-kindness, Karunā, or compassion, Muditā or sympathetic joy, and Uppekā or equanimity. In some respects, these abodes reflect aspects of contemporary Western understandings of empathy and compassion. However, they also elaborate upon and differ significantly from these understandings. North American learning outcomes, particularly in such areas as English language arts and peace education, seek to support the cultivation of emotional literacy in students with the hopes that such cultivation will initiate and enhance responsive and responsible relations with self, other, and environment. Insight into these abodes can consequently shed light on possibilities for deepening ethical, emotional, and educational engagement in North America.
This document is protected by copyright law. Use of the services of Erudit (including reproduction) is subject to its terms and conditions, which can be viewed online.

https://apropos.erudit.org/en/users/policy-on-use/ 


\title{
Heartmind Literacy: Compassionate Imagining $\mathcal{E}$ The Four Brahmavihāras
}

\author{
CLAUDIA EPPERT \\ University of Alberta, Canada
}

\begin{abstract}
This paper addresses the primacy of reason over emotion in much of Western philosophy and education. It brings Theravadan Buddhist wisdom to bear upon Western philosophical and educational conceptions of emotion, empatby, and compassion. More specifically, it discusses the four Brabmavihäras, or Divine Abodes. These abodes are considered boundless states of heartmind awareness that dismantle the bifurcation of mind/emotion and embody ideals of social engagement and peace. If cultivated, or dwelled in, they can overturn negative and destructive impulses, freeing the mind from greed, hatred, and delusion. They include Mettāa, or loving-kindness, Karunā, or compassion, Muditā or sympathetic joy, and Uppekā or equanimity. In some respects, these abodes reflect aspects of contemporary Western understandings of empathy and compassion. However, they also elaborate upon and differ significantly from these understandings. North American learning outcomes, particularly in such areas as English language arts and peace education, seek to support the cultivation of emotional literacy in students with the bopes that such cultivation will initiate and enhance responsive and responsible relations with self, other, and environment. Insight into these abodes can consequently shed light on possibilities for deepening ethical, emotional, and educational engagement in North America.
\end{abstract}

When compassion fills my heart,/free from all desire, I sit quietly like the earth./My silent cry echoes like thunder/throughout the universe.

Rumi, Whispers of the Beloved

\section{Introduction}

As many observe, a good deal of Western scholarship has stayed away from giving detailed attention to the life of the emotions in favor of examinations of reason and cognition, even in studies centered on possibilities for personal and sociopolitical transformation. For example, as Mahabodhi (2010) cogently puts it:

It is as if in modern philosophy there is a general view that thinking is all one does to solve the problems of living. Yet the effect of this on the psyche is often certain flatness or deadness no matter what the philosophy is or says. Worse, in its content, the philosophy may elevate reason

(C) Copyright 2010. The author, Claudia Eppert, assigns to Paideusis the right of first publication and educational and non-profit institutions a non-exclusive license to use this document for personal use and in courses of instruction provided that the article is used in full and this copyright statement is reproduced. Any other usage is probibited without the express permission of the author. 
over emotion, and that has a further dampening effect on the colour and inspiration of life. (p. 168)

Michalinos Zembylas (2008) and others contend that emotions have been disavowed in philosophical and educational contexts in favor of knowledge-driven and objective critical inquiry, or they have been hegemonically disciplined, or they have been presented as individual experiences with little or no recognition or study of how they are socio-politically constructed. The disavowal or disciplining of emotion has made affective engagement discomforting and anxiety-ridden for educators: What do we do with intense, varied, conflicting affects? How do we understand and talk about affects and emotions? These are questions we need to explore more fully in educational theory and practice in recognition that we are beings able to experience, conceive of, and choose between compassion and hatred.

In recent years, there has been a turn to more scholarly interest in the emotions, interest that has included study of the complexities of empathy and compassion. Notions of empathy have been examined particularly with regard to its limitations and possibilities in the arts, in education, and with reference to social suffering and social justice initiatives. Scholars are seeking to understand empathy in its distinctions from pity and sympathy and its relationship to the idea of "stepping into another's shoes" (Spelman 1992; Zembylas 2008). Compassion has been receiving similar academic attention (Berlant 2004; Frakes 2007; Ladner 2004; Nussbaum 2003). While compassion is a hugely significant part of Christian theology, secularized society—with its emphases on materialism and the pursuit of individual happiness - has in some ways diminished its presence in our everyday vocabulary. Lee Yearly (1997) observes that "Western philosophical thought has discarded compassion as the basis for an ethical system along with the rejection of religion" (p. 11). At the same time, however, Marjorie Garber (2004) has observed its increased and varied deployment in American political and social life; including the iconic "I feel your pain" statements of Bill Clinton, the compassionate conservatism of the Bush campaign, and the creation of the term compassion fatigue in the late twentieth century, which has been used to describe weariness of Americans to "react to suffering abroad and ... respond to yet another disaster" (pp. 18-19).

This paper introduces Buddhist understandings of emotion, compassion and empathy into what to-date is a largely Western-based examination of these concepts within North America. As mentioned elsewhere (Eppert and Wang 2008), the Asian wisdom traditions continue to be largely marginalized in Western discourse. I sometimes hear a reluctance to engage Buddhist ideas out of concern that these ideas are not approachable from within a Western worldview. Yet, it must be remembered that East and West have an extensive history of cultural, economic, philosophical and spiritual exchange (Smith 2008) and that Buddhist sages have been bringing their philosophies to the West for quite some time now in the very hopes that more individuals, East and West, will embrace these philosophies. Insight into the Asian traditions is valuable for fostering intercultural dialogue and examining possibilities for peace in a violence-ridden world. All the major philosophical systems and sages that came on the scene during the Axial Age (c. 800-200 BCE) introduced the necessity of a more compassionate worldview: Hinduism, Daoism, Confucianism, Greek Rationalists, and the prophets of the Middle East, among others (Armstrong 1993, 2005). My discussion of compassion primarily draws from the Theravadan tradition, specifically the four divine abodes or Brahmavihāras. Buddhaghosa, a fifth century Indian Theravadan Buddhist scholar, discussed these abodes in his well-known work, the Visuddhimagga, or The Path of Purification. References to the abodes also appear throughout the Pali canon. In my view, the Brahmavihāras importantly heighten awareness of the value in fostering positive feelings in educational life that can potentially revitalize the public sphere. As Lorne Ladner (2004) writes in The Lost Art of Compassion, one can go through "many years of Western education without learning how to develop positive emotions. These qualities are essential to our own happiness, to healthy relationships, and to the well-being of society, but learning to cultivate them is not seriously addressed in our culture, educational systems, or traditions of psychology" (p. xiii). Our medical culture, she continues, is largely 
founded on pathology, on a disease model of repairing human beings rather than a model that strives to promote health and well-being (p. xiv). This paper is part of a larger initiative to contribute to the reconceptualization of healing within North American and the exploration of what I have been calling an "intercultural healing ethic."

\section{Uses and Abuses of Compassion}

While a comprehensive overview of compassion is considerably beyond the scope of this paper, I do want briefly to introduce certain challenges two scholars have identified with this concept in its European and North American articulations. Garber (2004) traces compassion's Western etymological history from its earliest times to its present American expression with a view to showing how the concept is ironically not as compassionate as would seem. For example, she notes that from the $14^{\text {th }}$ to the $17^{\text {th }}$ century the word, compati, which is joining of com, meaning "together with" with pati meaning "to suffer" primarily meant the "suffering together with another, participation in suffering and "fellowfeeling." It was synonymically identified with sympathy and fellow-feeling. It also described "the feeling or emotion, when a person is moved by the suffering of distress of another, and by the desire to relieve it." She notes how, in this second sense, compassion was experienced not as among equals but from a place of distance if not some condescension, as the compassionate person was free of the sufferer's suffering (p. 20). In later usage, particularly in religious contexts, the term emphasized the benefits of compassion to the non-sufferer, invoked in the phrase "the compassionate one" (p. 21). Pleasure and pain co-mingled in the experience of the compassionate one, whether God, monarch, saint, or man, and both Garber and Bill Pinar (2001) identify suspect, possessively erotic undertones in expressions of compassion and empathy. Garber concludes with regard to compassion that it is this "question of the abject other in need of assistance that has been the undoing of compassion as well as its proudest boast" (p. 24, her emphasis), and quotes George W. Bush's oddly militant campaign stump about "rallying the armies of compassion" (p. 34).

Philosopher and literary theorist Martha Nussbaum similarly observes the uses and abuses of compassion, particularly in the wake of 9/11. In her "Compassion and Terror" (2003) article, she poses the question: "Is compassion, with all its limits, our best hope as we try to educate citizens to think well about human relations both inside the nation and across national boundaries?...Or is compassion a threat to good political thinking and the foundations of a truly just world community" (p. 12). She examines what this paper will identify as a "weak compassion" among some Americans post 9/11. This expression depends upon divisions between self and others, often articulated as "us versus them," is experienced more strongly in circles of greater common attachment, and tends to be fleeting. Nussbaum stresses, for example, how Americans extended concern to fellow Americans post 9/11 while the Rwandan genocide left many unaffected. She observes that, in the face of the unreliability of compassion, it is no wonder Western philosophical tradition has sought "to do away with compassion as a basis for public choice" and instead turned to "detached moral principals," such as human worth and dignity" (p. 17). The remainder of her article details her view of the limitations of the concept of dignity and argues for the final importance of compassionate imagining, even in the face of its dualistic unreliability. Because of space constraints, I encourage the reader to read these provocative texts to acquire more detailed understanding of current critiques of compassion. In what follows, however, I seek to bring to this scholarship a Buddhist perspective, as I believe doing so sheds important light on the Western commodification of compassion and the self/other dualism so dominant in much current understandings. 


\section{Bodhicittta}

In Theravada Buddhism, compassion constitutes one of the Four Divine Abodes, or Brahmavihāras. These Abodes are considered positive qualities of heartmind. In Buddhist language and thought, heart and mind are conjoined. While Western discourse has long separated qualities of mind from emotion and affect, in Pali, the dialect of the earliest Buddhist scriptures, heart and mind are referenced together in the word, citta. Although a complicated and variably defined word, according to the dictionary of the Pali Text Society (2007), citta is:

the heart (psychologically), i.e. the centre and focus of man's emotional nature as well as that intellectual element which inheres in \& accompanies its manifestations; i.e. thought... The meaning of citta is best understood when explaining it by expressions familiar to us, as: with all my heart; heart and soul; I have no heart to do it; blessed are the pure in heart; singleness of heart (cp. ekagga). (p. 266)

As Mahabodhi (2010) observes, the dictionary definition emphasizes the emotive side of mind over the intellect or mind-sense. He states that, not unlike the Greek Thymos, citta has connotations that are subjective, emotional, cognitive, and bodily. As citta arises on the bases of certain dependent conditions or a matrix of dependent conditions, it can encompass both heart and mind, and different types or shapes of citta can manifest, some more inclined to assume the shape of a particular thought or emotion or bodily awareness (again, recognizing, however, that these are not purely separable). To define citta as mind or emotion or body is to objectify what is basically an interdependent process. Citta is movement, the "psyche moving in creative response or in reaction to experience" (p. 140). Mahabodhi (2010) observes that as heart and mind are always shaping themselves in some way, we must ask whether the shaping is merely reactive or productively creative (p. 144).

Buddhism aspires to the cultivation of Bodbicitta, which is the wish to attain enlightenment for the benefit of all beings trapped in a cyclic existence of samsara. Bodhicitta is citta's enlightened counterpart. It is the heartmind of a being on the path to enlightenment, and means "the good heart" or "awakening heart" (Hattam, 2008, p. 116). As Mahabodhi writes, "it is the emotional outpouring of positive impulse towards all sentient beings; it is both cognitive and emotional" (p. 146). Robert Hattam (2008) describes Bodhicitta as the spontaneous experience of "love and compassion for all beings without exception" (p. 166). He observes that it is a term not well-known in the West and emphasizes that it is not simply affective. He writes,

Our metaphor for the heart as the site of our love or compassion hides more than it illuminates. For Buddhists, love and compassion, or concern for the welfare of others, are not feelings but types of awareness. Love and compassion arise and abide in our minds.... In thinking about bodhicitta, the metaphor of mind/heart might be more appropriate (p. 116).

Pema Chödrön (1997) describes bodhicitta as "tenderness for life" or "our soft spot" that is inherent in all human beings (p. 86).

\section{The Four Divine Abodes}

The cultivation of the four abodes, or what Ayya Khema (2001) identifies as the "four friends," is intended to move one away from the experience of greed, hatred, irritation, distress, restlessness and other harms. They include Mettä, or loving-kindness, Karunä, or compassion, Muditā or sympathetic joy, and Uppeka or equanimity. They are called friends because they are recognized as lofty or sublime or boundless states of awareness that embody ideals of social engagement and inner and world harmony. 
It is held that over time, the four abodes will begin to govern one's thoughts and actions easily. Human beings are all capable of such cultivation, because the seeds of the four abodes are inherently within us, connecting us to the stream of goodness and to the world. They are considered abodes (vihāra) because ideally they are dwelling-places, a home in which one constantly resides, rather than a place one visits. They are also known as "immeasurables," because, as Nhat Hanh (1998) describes, when practiced they keep growing (p. 1). These abodes cannot be mere words or concepts but must flow within the heart in order to be worthy: again, they are expressions of the heartmind (Khema, 2001). It is said that one who has fully cultivated these abodes will not carry any discrimination and ill will towards self or other, whether in regard to another's personality traits, actions, physical qualities, gender, socio-economic status or nationality. Each of the abodes has a near enemy and a far enemy. The near enemy is a likeness to the abode, but a false likeness, differing from it in important respects, while the far enemy constitutes the abode's opposite.

\section{Mettā}

Mettā is generally translated as loving-kindness, although as Frakes observes, it has also been nonliterally translated as "unconditional love" or "gentle friendship" (p. 114). I particularly appreciate Buddhist practitioner DaeJa Napier's (2004) poetic interpretation of the four abodes. She likens mettā "to a soft rain that penetrates the heart, relaxing the defense mechanisms associated with fear or ill will.... As the heart inclines toward mettā it begins to feel a fondness for oneself and others that can be expanded to include everyone." Mettā's near enemy is selfish affection while its far enemy is ill will. The cultivation of mettā facilitates the overcoming of annoyance and hatred and transpires in the embodied recognition of the worth of all sentient beings and the desire to wish them well. Nyanaponika Thera's (1994-2010) contemplation on lovingkindness is similarly poetic:

Love, that lies like a soft but firm hand on the ailing beings, ever unchanged in its sympathy, without wavering, unconcerned with any response it meets. Love that is comforting coolness to those who burn with the fire of suffering and passion; that is life-giving warmth to those abandoned in the cold desert of loneliness, to those who are shivering in the frost of a loveless world, to those whose hearts have become as if empty and dry by the repeated calls for help, by deepest despair. Love, that is a sublime nobility. Love, that is a sublime nobility of heart and intellect which knows, understands and is ready to help. Love, that is strength and gives strength: this is the highest love. (p. 15)

This description also emphasizes an interdependent relationship between mind and emotion. That love is "unconcerned with any response it meets" should not be understood to mean that one is emotionally or cognitively indifferent but rather that it is an available love, without discrimination and condition.

\section{Karunā}

Karunā is compassion, which Napier (2004) describes as a "quivering commiseration in the heart." She elaborates: "The compassionate heart is softer than the petals of a flower. As the heart opens with acceptance, it becomes large enough to hold our existential suffering with trust and respect." It is accepting rather than judgmental. Practicing compassion can open one up to the sustained and unobstructed mindfulness that is required for "the darker side of life [to be] lifted into the light of awareness" (Napier, 2004). The near enemy of compassion is pity as pity contains aversion within it, while the far enemy of compassion is cruelty, in which there is no mercy. I will return to karunā shortly, but first I want to introduce the last two abodes. 


\section{Muditā}

Muditā, generally translated as "sympathetic joy," is the capacity to unselfishly rejoice at the prosperity of others. Napier (2004) writes that "it is likened to a flower at full bloom. It is the ability to appreciate something as it is blooming and releasing the fragrance of its happiness.... [It is] exemplified in the mother-child connection when the child begins to express its own creative nature. [It] is the ability to join and support this expanding spirit." It is grounded in an a priori friendliness and affection for another, and it produces gratitude and generosity. Sympathetic joy should not be understood as something that is built on occasion in response to circumstance but rather as an infinite well from which one draws.

Nhat Hanh (1998) observes that joy does not discriminate between self and others (p. 7). It thus includes self-care, self-contentment, and self-appreciation. Self-appreciation or secure joy in one's own successes is not arrogance or conceit because it is cognizant of context and the many conditions that supported this appreciation and success, including the help and contributions of others. As Alan Wallace (2004) notes, there is rejoicing at those moments of aspirations and actions that were wholesome in nature (p. 146). The situation may arise in which another experiences a positive event while the self experiences a negative event or hardship; nevertheless, there is still a rejoicing within the self for another, as the situations are not enviably compared and contrasted. Sympathetic joy is thus enabled when it emanates from a secure sense of one's own abundance rather than from a sense of insufficiency. Thera (1994-2010) maintains that it helps compassionate action from being limited by condescension, indifference, or boredom. It helps counter the spirit of wanting to suppress or depress another's happiness. Its near enemy is the off-balance state of exuberance or giddiness that results from wanting to experience pleasure out of a sense of insufficiency or lack. Its far enemy is resentment, including cynicism and despair.

\section{Upekkhā}

Finally, Upekkhā is a quality of mind that balances the other three abodes and insures that they are "developed equally towards all beings" (Frakes, 2007). Napier describes equanimity as the

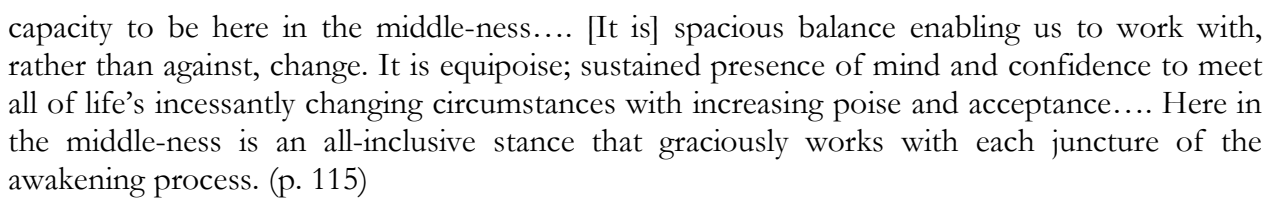
rather than against, change. It is equipoise; sustained presence of mind and confidence to meet all of life's incessantly changing circumstances with increasing poise and acceptance.... Here in the middle-ness is an all-inclusive stance that graciously works with each juncture of the awakening process. (p. 115)

Nhat Hanh (1998) observes how in the Sanskrit upeksha "Upa means 'over, and iksh means 'to look'. You climb the mountain to be able to look over the whole situation, not bound by one side or the other" (p. 8). In this regard, when one has equanimity, one does not react to a situation with physical or mental aversion but rather one responds with acceptance of things as they are. Indifference is the near enemy of equanimity while the far enemy is craving, attachment, and clinging.

\section{Brahmavihāra-Bhavana}

The four abodes cannot be mere objects of reflection but require the methodological meditation practice of Brahmavihāra-bhavana. According to Thera (1994-2010), meditative practice will have the effect of deepening these states within us, so they cannot be readily ignored, and also opening us up to their "boundless extension" or full range. The strengthening of the immeasurables will result in the gradual weakening or eradication of their near and far enemies. Meditation involves contemplation of the other and the exercise of extending positive states of mind toward him/her. One begins by bringing 
to mind a beloved one in one's nearest circle, and imagining their experience in as much detail as possible. Then one contemplates on what one has in common with the loved one, coming to recognize that the loved one shares similar motivations (e.g., the wish to seek happiness). One subsequently meditates on wishing that the loved one be free from their suffering, and seeks to practice extending loving-kindness to that person. Following repeated practice here, one begins to widen the circle of one's engagement, initiating the same practice with someone to whom one is indifferent and subsequently to someone one perceives as an enemy. Following this, one begins to break down barriers of distinction between friends and enemies, and extends loving kindness, joy, and compassion to all. To practice the Brahmavihāras with diligence or Khanti, meaning patience, thus is to cultivate conditions for awakening to our Dharma nature, to heal wounds, and to "restore magnamity" (Napier, 2004).

Furthermore, the Brahmavihāras are not separate but require each other and are mutually pervasive. For example, compassion stops loving-kindness and sympathetic joy from forgetting that there is more suffering in the world than either of these two qualities can mitigate, and that happiness co-exists with misery. Compassion additionally prevents these two qualities from becoming isolated from the world, as compassion includes a commitment of responsible and responsive action towards suffering. Conversely, sympathetic joy stops compassion from being overwhelmed by suffering, relieving one from tension and the possibility of melancholia.

\section{Samsara, the Five Aggregates, and Prannā}

The Brahmavihāras are a practice intended to release us from samsara. Variably translated as "continuous movement," "wandering on," or "wheel turning," samsara refers to the cycle of birth, death, and rebirth. This cycle is one of creating worlds of suffering as a result of our false spatial and temporal views concerning the nature of reality. We believe that there is such a thing as permanence and such a thing as a contained/containable self. In reality, things are always changing (impermanent), and there is no grounding in a separate, sovereign self to be had. Samsara is experienced through the five khandhas (Pali) or skandhas (Sanskrit) or five aggregates (heaps, bundles); that is, composites or objects of clinging that comprise the basis for a sense of a separate self, an "I": 1) form , or the material world (e.g., sound, sight connected to ear, eye) ; 2) sensation in response to an object; 3) perception, or the registration of the recognition of an object; 4) mental formations, or mental habits, thoughts, ideas, opinions and actions regarding an object; 5) consciousness, or discernment.

The first aggregate, form, constitutes the birth of the ego, in which there is a stubborn ignorance of limitless space and egolessness. According to Chögyam Trungpa's (1971) discussion of the aggregates, a gap or space occurs in the experience of mind. The glimpse of openness is followed by an abstract discomfort or anxiety that there may be no foundational self, and a process of wanting to create some solidity in empty space ensues. The second aggregate he describes, (vedanā), is a physical sensation, feeling or affect through the six sense organs, including mind. It can be pleasant, painful, or neutral, and begins the projective process of holding on to what is pleasant, to what reassures us of some stable existence. The third aggregate is the web of perceptive associations one draws in relation to pleasure, pain, and what one experiences as neutral. It is the strategy of sense-making, controlling, reporting what is occurring in a moment in ways that further construct solidity. Trungpa maintains that, in the second and third aggregates, liking or non-liking arise. Passion (desire), aggression, and indifference characterize three impulses of the third aggregates. Momentum gathers as the fourth aggregate is a karmic reaction to the second and third aggregates: one acts out on the basis of liking or non-liking. If the previous aggregates were more instinctive or impulsive, the fourth aggregate is intellect or conceptualization, processes of naming and categorization. The fifth aggregate is the coordinated production of a bifurcated consciousness, and separation of self from other and environment. It is a composite of thought patterns and emotions that support a fantasy narrative of me. 
A commonly referenced more concrete example of these aggregates is our relationship to our bodies. I might believe that my body is "me," and become invested in it. If my body continually conforms well to my and/or my society's wants and expectations, to the mental idea/ideal of a good body (e.g., youthful, thin, fit), I am happy. If not, I am unhappy. As Chödrön (1997) maintains, "thinking that we can find some lasting pleasure and avoid pain is what in Buddhism is called samsara, a hopeless cycle that goes round and round endlessly and causes us to suffer" (p. 9)

To overcome investment in an unchanging separate self, one needs to be able to recognize and unpack the five aggregates composing us. Pannā (Pali) or Prajnā (Sanskrit) is wisdom, or "clear seeing." It is the heartmind shaped by meditative discernment. It is the concentrated, embodied, and intuitive insight into Buddhist notions of impermanence, suffering, and no-self, and leads to enlightenment and the cessation of suffering. Vision is no longer obstructed by desire, hatred, concepts, imagination, and beliefs. Clear seeing into how we are a composite of five aggregates begins to dismantle the notion of "me" and "mine" and concurrently breaks down the self/other divide. We acquire insight into the commonality of the suffering of samsara, while concurrently not discounting contextual differences. Through hearing, contemplating, meditating, one gains recognition of interdependence and everything comes to be seen in relation to everything else.

\section{Emotional Literacy}

Buddhist insights contribute to Western perspectives not only by integrating emotion, body, and mind but also by distinguishing between reactive heartmind conditioned by samsara and responsive heartmind conditioned by enlightenment. As such, there is a distinction between unskillful and skillful emotions. Buddhism emphasizes the importance of bringing mindfulness and meditation to emotional and mental states, and to the conditions, contexts, and effects of these, such that "the practitioner leaves behind their neurotic infatuations with the world" (Mahabodhi, 2010).

Yet, that is not to say that one needs to repress or empty oneself of emotion, as is often asserted by those unfamiliar with its tradition. What Buddhism seeks to foster is intricate awareness of one's sensations, feelings, emotions, and thoughts. The invitation is not to hide, deny, suppress, or run from these, but rather to "sit" with them, to very intimately get to know them and their causes and results. As one becomes more and more familiar with them, one comes to see how and in what measure they continually arise and fall away, and the details of their conditioning. Negative emotions and thoughts are to be greeted and explored not with disparagement or despair but with gentleness and lovingkindness, with curiosity, awareness, and embrace rather than criticism. This process will naturally lead to the diminishment of destructive thoughts and feelings, as they will inevitably lose the power they once had. Nor is it that mindfulness practice, for the average person, is likely ever to eradicate fully one's negative reactions: rather, skill is developed in not indulging or running from them in the times they do arise.

Clear seeing includes emotions. As practitioners come to discern the truth or untruth of mental objects in their minds, they also come to

shift their emotions in that direction. That is, they get more emotionally behind whatever they have decided is the case intellectually.... The involvement of emotion with a particular view holds it in the mind, and this is what having faith in something means-we are emotionally committed to it. (Mahabodhi, 2010, p. 201)

Because of clear seeing, how and what to invest one's emotional energy in becomes apparent. One acquires an intuitive, embodied insight into reality and illusion, and the consequent possibilities of love and compassion, and also compassionate action. According to Mahabodhi, you just know what is right 
(2010, p. 202, my emphasis). In some respects, compassion combined with clear seeing loses the quality of unreliability defined by Nussbaum.

Emotional literacy and emotional intelligence are terms that have been gaining credence in recent years. While these are variably approached, as Zembylas (2005) notes in his detailed account, the common emphasis within their implementation in much emotional literacy curricula seems to be upon learning to identify and develop 'emotion management 'skills' or 'competencies' within an informational paradigm and for such purposes as achieving workplace success, and personal and relationship growth (pp. 47, 161). Buddhism sheds light on these concepts multiply: through a nuanced, non-judgmental contemplative inquiry into sensations, feelings, emotions, thoughts in their interdependence; through the introduction of specific positive emotions and skills by which to cultivate them; and, importantly, through the provision of an overarching interpretative framework. In other words, roughly put, one can identify emotions as they operate within a particular container or one can explore emotions in ways that are combined with processes of clear seeing, such that the very container beckons questioning and revaluation, the container being one's worldview, one's self-narrative, one's societal norms, the nature of mind and emotion, and one's possibilities for living and acting in the world, alone and with others.

\section{Rethinking Empathetic Imagining}

I return to the problematization of Western compassion and empathy introduced at the beginning of this paper. Within Western liberal humanist understandings, empathetic practices are connected to the development of compassion. In educational circles, empathetic engagement has long involved imagining oneself into the experience of a literary character in the hopes of coming to greater understanding and responsiveness. Contemporary scholarship has identified the limitations of this perspective: namely, that empathetic identification too readily falls into the danger of collapsing differences between self and other, as the other is presumptively reduced to a version of the self. Zembylas (2008) offers a synthesized understanding of recent literature on empathy that illuminates a more nuanced view. He defines empathy as "the ability to incorporate other people's perceptions and see an experience with their eyes" (p. 48). At the same time, he cautions that empathy does not mean identification with another or even necessarily agreeing with the other but rather a willingness to resonate emotionally with and imagine another's perspective and situation. As well, it includes the critical and analytical ability to recognize that another is as deeply motivated and complex as oneself. While there is the effort to open up to, connect with and take responsibility for another's experience, there is additionally an appreciation that the other is also unknowable, cannot be stereotyped, categorized, or conclusively understood-he or she is too multifaceted for any fully imagined comprehension (Zembylas 2008, p. 65).

The meditative practice of the brahmavihāras suggests affinities with Western educational practices of imaginative identification, as the practitioner seeks to contemplate and imagine the experience of another in all its possible detail. Yet, there is a substantive difference between these practices, because Buddhism challenges the practitioner to connect with another's experience while aspiring to let go a restrictive and reactive samsaric worldview that would support ego-centered projection and reduction. This process has implications for the Western definition of compassion insofar as Western compassion is defined as opposed to reason, or as a "suffering with," or potentially even, a "resonating with."

Chris Frakes (2005) nicely illuminates how Buddhist insights complexify Western conceptions of compassion and empathy. In ways that echo Garber's view, Frakes writes, "one of the major problems with understandings of compassion found in western philosophical sources is that such descriptions routinely connect compassion with the experience of sorrow and pain." (p. 102). Compassion as imagining the perspective of another and participating emotionally in another's suffering by 
experiencing pain in reaction to another's pain runs into trouble if there is the assumption that one is feeling the same pain and that compassion increases in the measure that pain is appropriated.

I appreciate Frakes' (2005) concerns regarding the question of what "taking on the other's pain really means" (p. 108):

To suggest that one can feel another's pain is to claim that somehow responsiveness to another's pain involves a type of emotional infection. Even if this sort of psychological contagion is possible, I do not believe it is to be recommended. Becoming mired in the suffering of others such that one's emotional experience is that of overwhelming anguish, fear, or pain leads one away from the ability to effectively engage with the suffering other and into one's own psychological experience. 'Taking on another's pain' creates a situation in which the responder is no longer focused externally upon the plight of the suffering other, but instead becomes referentially and internally focused. Further, ...coming to identify with another's situation by imaginatively dwelling on their plight becomes problematic in that 'these imaginings [could be] no more than flights of fancy, with little or no basis in actual fact.' More important than feeling another's pain, then, is coming to understand what they suffer so as to be able to respond and, where possible, to alleviate that suffering. (p. 108).

The taking on of another's suffering thus has the possibilities of obstructing rather than facilitating compassion.

As such, Frakes (2005) writes, with reference to the brahmavihāras, that karunā "succeeds when it makes cruelty subside and it fails when it produces sorrow...unlike Western understanding...a Buddhist understanding of compassion is not linked to sorrowing" (p. 114). In my view, however, this should not be taken to mean that karunā is without emotion. Rather, karunā is embodied heartmind awareness and experience that includes an expansiveness of genuine heartfelt concern for the suffering and welfare of another, without, however, concurrently being linked to dualistic samsaric pleasure/pain and egocentric clinging or aversion. It is in this context that we might perhaps more fully understand Rumi's poetic lines stated at the outset of this paper: compassion is distinguished from samsaric desire, enabling him to be still/peaceful. Yet, this stillness includes a silent cry, as it is not free of heart. It is enlightened heartmind; that is, emotion combined with perfect wisdom. Similarly, as Hattam (2008) observes, quoting Chögyam Trungpa, "awakening one's heart involves living with the 'tremendous sadness' when 'we open our eyes to the rest of the world"' (p. 116).

This returns us to the difference between citta and bodhicitta. Although diverse interpretations abound, in general, citta references both heart and mind (and body). Bodhicitta references a nonviolent, spontaneous, open heart of an awakening and awakened mind, the union of compassion and nonconceptual clear-seeing (Chödrön 2006 p. 76). Frakes writes, "the untrained emotion of compassion alone cannot be relied upon as properly action guiding" (p. 102). Genuine compassion is cultivated response and requires an "equanimitous disposition" (p. 102). Acarya Godwin Samararatne (1998) relates a practical example of the difference between untrained and trained compassion in his discussion of the four abodes. He asks one to envision walking down a street and encountering someone suffering on the side of the road because he/she has fallen. Without cultivation of the four abodes, one might be inclined to walk past the person with indifference or ill will, thinking perhaps this is not my problem. Or one might be full of anxious feelings, such as what if I help but this person pulls me down, or one might be so distraught by the suffering that one becomes overwhelmed with tears and cannot respond, and so on. Or one might become judgmental of the other person, criticizing him/her for not being more careful. Or one might become full of conceit or self-importance upon helping this person. All such reactions inhibit rather than support compassionate response and action. However, with cultivation of the four abodes, one can respond with lovingkindness, compassion, and equanimity to what has happened, cherishing and aiding the other person as that person requires, without making this aid about the self's ego. As Charles Scott (personal communication, September 4, 2010) observes, one the hallmarks of this compassion is that is that it confirms the presence of the other in her/his/its 
fullness. This strong rather than weak compassion would not suffer from the condescension described by Garber or the dualistic post 9/11 worldview articulated by Nussbaum. Hattam (2008) writes that "it is the mind/heart that is required if we are to get beyond the notion of 'insiders' and 'outsiders'." (p. 116). Chödrön (1997) maintains that "in difficult times, it is only bodhicitta that heals" (p. 87).

\section{Acknowledgments}

My thanks to Kathy Dawson for the resources to which she introduced me. Thanks also to Charles Scott for his careful editing and astute insights. Previous versions of this paper were presented at the Philosopby of Education Society of Australasia (2009) and the Canadian Society for Studies in Education (2009).

\section{References}

Armstrong, K. (1993). A History of God: The 4000-year quest of Judaism, Christianity, and Islam. New York: Gramercy Books.

Armstrong, K. (2005). A short history of myth. Toronto, ON: Vintage Canada.

Berlant, L., Ed. (2004). Compassion: The culture and politics of an emotion. New York: Routledge.

Chödrön, P. (1997). When things fall apart. Boston, MA: Shambhala.

Chödrön, P. (2006). Practicing peace in times of war. Boston, MA: Shambhala.

Easwaren, E. (1985/2007). The Dhammapada. Tomales, CA: Blue Mountain Center of Meditation.

Eppert, C. \& Wang, H., Eds. (2008). Cross-cultural studies in curriculum: Eastern thought, educational insights. Mahweh, NJ: Lawrence Erlbaum/Routledge, Taylor \& Francis.

Frakes, C. (2007). Do the compassionate flourish? Overcoming anguish and the impulse towards violence. Journal of Buddhist Ethics, 14, 99-128.

Garber, M. (2004). Compassion. In L. Berlant (Ed.), Compassion: The culture and politics of an emotion. New York: Routledge.

His Holiness the Dalai Lama (1999). Ethics for a new millenium. New York: Riverhead.

Hattam, R. (2008). Socially-engaged Buddhism as a provocation for critical pedagogy in 'unsettling times.' In C. Eppert \& H. Wang (Eds.), Cross-cultural studies in curriculum: Eastern thought, educational insights (pp. 109-136). Mahweh, N.J.: Lawrence Erlbaum/Routledge, Taylor \& Francis.

Khema, A. (2001). Being nobody, going nowhere: Meditations on the Buddhist path. Somerville, MA: Wisdom Publications.

Ladner, L. (2004). The lost art of compassion: Discovering the practice of happiness in the meeting of Buddhism and psychology. San Francisco: HarperCollins.

Mahabodhi (2010, manuscript in progess). What is mindfulness?: Buddhist doctrine and method in the Satipatthana Sutta. Retrieved April 29, 2010, from http://www.mahabodhi.org.uk/.

Moyers, B. (2009). Interview with Karen Armstrong. Retrieved April 29, from http://www.pbs.org/moyers/journal/03132009/watch.html

Napier, D. (2004, June/July). The Brahma-Viharas. Northwest Dharma News, 17(4), (Northwest Dharma Association). Retrieved May 20, 2009, from http://www.brahmaviharas.org/articleTheBrahmaViharas.htm.

Nhat Hanh, T (1998). Teachings on love. Berkeley, CA: Parallax.

Nussbaum, M. C. (2003). Compassion and Terror. Deadalus, 132, (Winter), 10-26.

Pali Text Society (2007/1921-1925). The Pali Text Society's Pali-English dictionary. London: Chipstead. Retreived from http://dsal.uchicago.edu/dictionaries/pali/.

Pinar, W. F. (2001). The gender of racial politics and violence in America: Lynching, prison rape, and the crisis of masculinity. New York: Peter Lang. 
Samararatne, G. (1998, October 10). Metta, Karuna, Mudita, Upekkha. In The basics of meditation. Retrieved April 29, 2010 from http://www.godwin-home-page.net/Living-Meditation-HK98/Basics-04.htm).

Smith, D.G. (2008). The farthest west is but the farthest east: The long way of Oriental/Occidental engagement. In C. Eppert \& H. Wang (Eds.), Cross-cultural studies in curriculum: Eastern thought, educational insights (pp. 1-33). Mahweh, N.J.: Lawrence Erlbaum/Routledge, Taylor \& Francis.

Spelman, E. V. (1992). Fruits of sorrow: Framing our attention to suffering. Boston, MA: Beacon.

Rinpoche, Chogyam Trungpa (1971), The five skandhas. Garuda Magazine. Retrieved April 29, 2010 from http://www.beezone.com/Trungpa/fiveskandas.html.

Thera, N. (1994-2010). The four sublime states: Contemplation on love, compassion, sympathetic joy, and equanimity. Retrieved May 20, 2009, from http://www.accesstoinsight.org/lib/ authors/nyanaponika/wheel006.html.

Wallace, B.A. (2004). The four immeasurables: Cultivating a boundless heart. New York: Snow Lion Publications.

Yearley, L. (1997). Three views of virtue. In D. Goleman (Ed.), Healing emotions: Conversations with the Dalai Lama on mindfulness, emotions, and health. Boston, MA: Shambhala.

Zembylas, M. (2005). Teaching with emotion: A postmodern enactment. Greenwich, CT: Information Age Publishing.

Zembylas, M. (2008). The politics of trauma in education. New York: Palgrave, Macmillan.

\section{About the Author}

Claudia Eppert is associate professor at the University of Alberta, Canada. She is co-editor, with Roger I. Simon and Sharon Rosenberg, of Between Hope and Despair: Pedagogy and the Remembrance of Historical Trauma (Rowman and Littlefield, 2000) and co-editor, with Hongyu Wang, of Cross-Cultural Studies in Curriculum: Eastern Thought: Educational Insights (LEA, Taylor and Francis, 2008). Cross-Cultural Studies received AESA Critics Choice Award and also recently received Outstanding Book Recognition from AERA's Curriculum B Division. For more information on these books and her other publications, visit http://www.uofaweb.ualberta.ca/secondaryed/Eppert.cfm. She can be reached at eppert@ualberta.ca 